Çoşkun, M. ve Çetinkaya, S. (2018). Birleştirilmiş sınıflarda ve müstakil sınıflarda öğrenim gören 1 . sınıf öğrencilerinin okuduğunu anlama becerisinin değerlendirilmesi. Ana Dili Eğitimi Dergisi, 6(4), 987-1002.

$\begin{gathered}\text { Ana Dili Eğitimi Dergisi } \\ \text { Journal of Mother Tongue Education } \\ \text { www.anadiliegitimi.com }\end{gathered}$
Gelis/Received: 17.07 .2018 Kabul/Accepted:03.09.2018

\title{
Birleştirilmiş Sınıflarda ve Müstakil Sınıflarda Öğrenim Gören 1. Sınıf Öğrencilerinin Okuduğunu Anlama Becerisinin Değerlendirilmesi*
}

\begin{abstract}
Mehmet ÇOŞKUN**
Seher ÇETINKAYA***

Öz

Bu araştırmanın amacı, müstakil ve birleştirilmiş sınıflarda öğrenim gören ilkokul 1. sınıf öğrencilerinin okuduğunu anlama beceri düzeyleri arasında anlamlı bir fark olup olmadığııı incelemek ve bunun yanı sıra bu sınıflarda görev yapmış ya da yapan öğretmenlerin bu konudaki görüşlerini değerlendirmektir. Çalışmada öğrencilerden veri toplamak amacıyla Okuduğunu Anlama Becerisi testi kullanılmış, öğretmenlere ise araştırmacılar tarafından araştırma kapsamında geliştirilen yarı yapılandırıımış görüşme formu uygulanmıştır. Nicel verilerin çözümlenmesinde Mann Whitney $U$ testi, aritmetik ortalama kullanılırken; nitel verilerin çözümlenmesinde kategorisel analiz yöntemi kullanılmıştır. Araştırmadan elde edilen bulgulara göre birleştirilmiş sınıf ve müstakil sınıflarda öğrenim gören birinci sınıf öğrencilerinin okuduğunu anlama beceri düzeyi anlamlı bir farklılık göstermemektedir. Ancak öğretmen görüşlerine göre birleştirilmiş sınıflarda öğrenim gören öğrencilerin okuduğunu anlama başarı düzeyi daha düşüktür. Genel olarak öğretmenler birleştirilmiş sınıflarda daha çok güçlükle karşılaştıklarını belirtmişlerdir.
\end{abstract}

Anahtar Kelimeler: Okuduğunu anlama becerisi, birleştirilmiş sınıf, müstakil sınıf

The Evaluation of the Reading Comprehension Skills of First Grade Students Attending Multi-grade Classes and Single-grade Classes

\begin{abstract}
The aims of this research are to investigate whether there is a meaningful difference at the reading comprehension skill levels of first grade students in single-grade classes and multi-grade classes and to evaluate the opinions of teachers who have taught or are teaching in such classes. In the study, the Reading Comprehension Test was used to collect data from the students and the semistructured teacher interview form developed by the researchers was administered to the teachers. The Mann-Whitney $U$ test and arithmetical mean were used to analyze the quantitative data and the categorical analysis method was used in the analysis of the qualitative data. The research results show that there is no significant difference between the reading comprehension skill levels of elementary school students in single-grade and multi-grade classrooms. However, based on teachers' opinions, the reading comprehension skills of the students in multi-grade classes are lower. The teachers reported that in general they experienced more difficulty in multi-grade classes.
\end{abstract}

Keywords: Reading Comprehension Skill, multi-grade class, single-grade class

\footnotetext{
* Bu çalışma Ordu Üniversitesinde Dr. Öğretim Üyesi Seher ÇETiNKAYA danışmanlığında yürütülen “Birleştirilmiş Sınıflarda ve Müstakil Sınıflarda Öğrenim Gören 1. Sınıf Öğrencilerinin Okuduğunu Anlama Becerisinin Değerlendirilmesi" adlı yüksek lisans tezinden türetilmiştir.

** Yüksek Lisans, Ordu Üniversitesi, Eğitim Fakültesi, Temel Eğitim Bölümü, Ordu, mhmtcskn1907@hotmail.com.

${ }^{* * *}$ Dr. Öğretim Üyesi, Ordu Üniversitesi, Eğitim Fakültesi, Temel Eğitim Bölümü, Ordu, sbayat_cetinkaya@hotmail.com.
} 


\section{Giriş}

Birden fazla sınıfın birleştirilerek bir grup oluşturulmak kaydı ile bir öğretmen tarafından yetiştirilmesine birleştirilmiş sınıfta öğretim denir (Akbaşlı ve Pilten, 1999). Bir başka deyişle birleştirilmiş sınıflarda öğretim, farklı yaş, sınıf ve özellikteki öğrencilerin aynı grup içinde öğrenim görmeleridir (Little, 1994).

Ülkemizde öğrenci sayısının azlığı, öğretmen sayısı ve derslik sayısının yetersizliği gibi nedenlerden dolayı birleştirilmiş sınıflı öğretim uygulaması yapılmaktadır. Bu sebeplerin yanı sıra ülkemizin farklı sosyal, ekonomik ve coğrafi nedenleri birleştirilmiş sınıf uygulamasını zorunlu hale getirmektedir (Erdem, 2015). Birleştirilmiş sınıf uygulaması dünyanın birçok ülkesinde başvurulan bir öğretim şeklidir. AB ülkelerinin hemen hemen hepsinde, Japonya ve Kanada gibi pek çok ülkede de birleştirilmiş sınıf uygulaması yapılmaktadır (Erdem, 2015; Fidan ve Baykul, 1997). Ayrıca birleştirilmiş sınıf uygulaması belirli bölgelerle sınırlı kalmayıp ülkemizin her bölgesinde bulunmaktadır.

Birleştirilmiş sınıflarda yapılan öğretim ile müstakil sınıflarda yapılan öğretim birbirinden farklılık göstermektedir. Birleştirilmiş sınıflarda sistem, aynı ders saati içinde, bir grup öğretmenle ders işlerken, diğer gruba da ödevlendirme yapılarak grubun kendi başlarına çalışmalarını sağlamak üzere kurulmaktadır. Sınıfta öğretmen ayrı bir konu anlatırken diğer öğrenciler ayrı bir konu çalışmaktadır. Sadece mihver (eksen) dersler olan Hayat Bilgisi, Sosyal Bilgiler ve Fen Teknoloji dersleri ortak işlenmektedir (Palavan, 2012).

Farklı yaş seviyelerinde ve özelliklerde bulunan öğrencilerin bir arada eğitim aldıkları bu sınıflarda öğrenciler, sosyal gelişim ve bireysel öğrenme becerileri alanlarında bağımsız sınıflardaki öğrencilere göre nispeten kendilerini daha fazla geliştirme imkânı bulabilirken, birleştirilmiş sınıfların ekonomik ve fiziksel koşulları ise bu sınıfları tercih edilmeyen sınıflar haline getirmiştir (Bayar, 2009). Yöneticiler, öğretmenler ve aileler birleştirilmiş sınıf uygulamasının öğrenci başarılarını olumsuz yönde etkilediğini düşünmelerine rağmen Miller müstakil sınıflar ve birleştirilmiş sınıflar arasındaki başarıyla ilgili 13 deneysel çalışmayı incelemiş ve sınıf türleri arasında anlamlı farklılıklar olmadığını ortaya çıkarmıştır. Çok az sayıda veri, bağımsız sınıflarla birleştirilmiş sınıflar arasında, bağımsız sınıflar lehine anlamlı bir farklılık göstermektedir. Bu farklııklar da okul yaşamının karmaşık ve değişken doğasından kaynaklanmaktadır (Miller, 1991 Akt; Bayar, 2009).

Akademik hayatın ilk başarı ya da başarısızlık durumu ilkokuma yazma öğrenme döneminde yaşanır. Akademik hayatın yanı sıra Çelenk' e (2007) göre uygar toplumlarda bireyin kendi çabaladığı alanda ilerlemesi, önemli işlere imza atması, okuma yazma becerisine gelişmiş bir şekilde sahip olmasıyla mümkündür. Çünkü çağın gerektirdiği yeniliklere ayak uyduran insan etkin bir okuma becerisine sahip olmadan istenilen düzeyde bir bilgi birikimine sahip olamaz. "Okuma ve okunandan 
Birleştirilmiş Sınıflarda ve Müstakil Sınıflarda Öğrenim Gören 1. Sınıf Öğrencilerinin Okuduğunu Anlama Becerisinin Değerlendirilmesi

anlam çıkarma becerilerini kazandırmak, insanın hayatını anlamlı hale getirmesine yapılan en büyük katkı olarak eğitim programlarında ve öğretim sürecinde yerini almaktadır" (Akyol, 2010: 33).

Illkokuma yazma öğretiminin amacı sadece okuryazar yetiştirmek değil; doğru, akıcı, hızlı, anlamlı bir okuma gerçekleştirmek ayrıca okuduğunu anlama, anladığını anlatma, anlattığına yorum katma amacı doğrultusunda okuma yazmayı bilen nesiller yetiştirmektir (Demirel, 1998). Bireyin eğitim hayatında oldukça önemli bir yere sahip olan okuduğunu anlama becerisine öğrenim görüldüğü sınıf türü de etki edebilir. Bu nedenle birleştirilmiş sınıflarda ve müstakil sınıflarda öğrenim görmekte olan 1. sınıf öğrencilerinin okuduğunu anlama beceri düzeylerinin karşılaştırılmasının alana katkı sağlayacağı düşünülmektedir. Bu düşünceden hareketle araştırmada aşağıdaki sorulara cevap aranmıştır:

1. Birleştirilmiş sınıflarda öğrenim gören 1. sınıf öğrencileri ile müstakil sınıflarda öğrenim gören 1. sınıf öğrencilerinin okuduğunu anlama beceri düzeyleri nedir?

2. Birleştirilmiş sınıflarda öğrenim gören 1 . sınıf öğrencileri ile müstakil sınıflarda öğrenim gören 1. sınıf öğrencilerinin okuduğunu anlama beceri düzeyleri arasında anlamlı bir farklılık var mıdır?

3. Öğretmen görüşlerine göre;

a) Birleştirilmiş sınıflarda öğrenim gören 1. sınıf öğrencilerine okuduğunu anlama becerisi kazandırılırken karşılaşılan güçlükler nedir?

b) Birleştirilmiş sınıf türünün 1. sınıf öğrencilerine okuduğunu anlama becerisinin kazandırılmasında müstakil sınıf türüne göre üstün yanları nedir?

c) Birinci sınıf öğrencilerinin öğrenim gördükleri sınıf türüne göre okuduğunu anlama beceri durumları arasında fark var mıdır?

d) Hangi sınıf türünde okuma becerisini kazandırmada daha çok güçlük çekilmektedir?

\section{Yöntem}

\section{Araştırma Modeli}

Bu araştırmada müstakil ve birleştirilmiş sınıflarda öğrenim gören ilkokul 1. sınıf öğrencilerinin okuduğunu anlama beceri düzeyleri arasında anlamlı bir fark olup olmadığını incelemek ve bunun yanı sıra bu sınıflarda görev yapmış öğretmenlerin bu konudaki görüşlerini değerlendirmek amaçlandığından; nitel ve nicel araştırma desenlerinin birlikte kullanıldığı karma araştırma modellerinden açıklayıcı karma yöntem kullanılmıştır. Açıklayııı karma yöntem araştırmalarında nicel veriler toplanıp daha sonra nicel verileri açıklamak amacıyla nitel veriler toplanır (Creswell ve Plano Clark, 2014). Bu araştırmada ilk aşamada öğrencilerden nicel veriler toplanıp analiz edilmiş, sonraki aşamada öğretmenlerden nitel veriler toplanarak analiz edilmiş ve son olarak da sonuçlar birlikte yorumlanmaya çalışılmıştır. 
Araştırmanın nicel boyutu; ilkokul 1. sınıf öğrencilerinin birleştirilmiş sınıfta ve müstakil sınıfta öğrenim görme durumlarına göre okuduğunu anlamaya ilişkin beceri düzeylerini tespit etmeye yönelik olduğundan tarama modeline göre desenlenmiştir.

Öğretmenlerin; müstakil ve birleştirilmiş sınıflarda öğrenim gören 1. sınıf öğrencilerin okuduğunu anlama becerisine ilişkin düşünceleri ve görüşlerinin belirlenmesi araştırmanın nitel boyutunu oluşturmaktadır. Bu çalışmada; birleştirilmiş sınıflarda ve müstakil sınıflarda öğrenim gören 1. sınıf öğrencilerinin okuduğunu anlama beceri düzeylerinin ve bu öğrencilerin okuduğunu anlama beceri düzeylerine ilişkin öğretmen görüşlerinin ortaya konulması amaçlanmıştır. Çalışma, öğretmenlerin birleştirilmiş ve müstakil sınıfların yararları, sınırlılıkları bu sınıfta öğrenim gören öğrencilerin başarıları vb. görüşler açısından derinlemesine incelendiğinden dolayı araçsal durum çalışması olarak tanımlanabilir.

\section{Evren ve Örneklem}

Araştırmanın evreni; 2015-2016 eğitim-öğretim yılında Ağrı il merkezi ve köylerinde MEB' e bağı 150 ilkokulda öğrenim gören toplam 3501 adet birinci sınıf öğrencisinden oluşmaktadır. Bu okulların 61' i birleştirilmiş sınıf, 89' u ise müstakil sınıflardan oluşmaktadır. Araştırmanın örneklemini belirlemek için de bu okullardan tesadüfí (random) örnekleme yöntemiyle 36 adet birleştirilmiş sınıflı, 14 adet müstakil sınıflı olmak üzere toplam 50 okul seçilmiştir. Bu seçilen okulların birleştirilmiş sınıflarından 185, müstakil sınıflarından 185 olmak üzere toplamada 370 adet 1 . sınıf öğrencisi çalışmaya dâhil edilmiştir.

Araştırmada öğretmenleri belirlemek için ise amaçlı örnekleme yöntemlerinden ölçüt örnekleme yöntemi kullanılmıştır. Öğretmenleri belirlemede kullanılan ölçüt, birleştirilmiş sınıflarda ve müstakil sınıflarda görev yapmış olan öğretmenler olarak araştırmacı tarafından belirlenmiştir. Araştırmaya 20 sınıf öğretmeni katılmıştır.

\section{Veri Toplama Araçları}

\section{Öğretmen Görüşme Formu}

Öğretmen görüşleri araştırmacı tarafından hazırlanan yarı yapılandırılmış bir görüşme formu ile toplanmıştır. Görüşme formu hazırlanırken; öncelikle konuyla ilgili literatür incelenmiş, üç eğitim uzmanının (program geliştirme uzmanı, Türkçe dil eğitim uzmanı ve ölçme değerlendirme uzmanı) görüş ve önerileri doğrultusunda formda gerekli düzenlemeler yapılmıştır. Iki bölümden oluşan görüşme formunda birinci bölümde öğretmenlere ilişkin kişisel bilgiler yer almakta; ikinci bölümde ise birleştirilmiş ve müstakil sınıflarda öğrenim gören öğrencilerin okuduğunu anlama becerilerine ilişkin görüşlerini ortaya koymaya yönelik 4 açık uçlu soru yer almaktadır. 
Birleştirilmiş Sınıflarda ve Müstakil Sınıflarda Öğrenim Gören 1. Sınıf Öğrencilerinin Okuduğunu Anlama Becerisinin Değerlendirilmesi

\section{Okuduğunu Anlama Becerisi Testi}

'Okuduğunu Anlama Becerisi Testi' her biri üç seçenekten oluşan 25 maddeden meydana gelmektedir. Bu maddeler öğrencilerin okuduğunu anlamalarına ilişkin 10 beceriyi ölçmektedir. Bu becerilere ait veriler Tablo 1' de gösterilmiştir (Bayat, 2012, s. 189).

Tablo 1. Okuduğunu anlama becerileri ve soru sayısı

\begin{tabular}{ll}
\hline Okuduğunu Anlama Becerileri & Soru Sayısı \\
\hline 1. Okuduğu metne başlık bulma & 2 \\
2. Okuduğu metni özetleme & 2 \\
3. Okuduğu metnin konusunu belirleme & 2 \\
4. Okuduğu metinde ilgili soruları cevaplama & 6 \\
5. Okuduğu metinde sebep-sonuç ilişkisini belirleme & 3 \\
6. Okuduğu metindeki kişilerin özelliklerini söyleme & 2 \\
7. Okuduğu metin ile ilgili duygu ve düşünceleri ifade etme & 2 \\
8. Yarım bırakılan bir okuma metnin sonucunu tahmin etme & 2 \\
9. Verilen başlığa/görsele göre metnin içeriğini tahmin etme & 2 \\
10. Okuduğu metinlerden hareketle bilmediği sözcüklerin anlamını tahmin etme & 2 \\
Toplam & $\mathbf{2 5}$ \\
\hline
\end{tabular}

Üç seçenekli çoktan seçmeli testten oluşan okuduğunu anlama beceri testinde doğru cevaplar 1, yanlış cevaplar 0 puan ile değerlendirilmiştir. Toplam puanların ortalaması 10 tam puan esasına göre hesaplanmış ve uzman görüşlerine de başvurularak okuduğunu anlama beceri testinden alınan puanlara karşılık gelen düzeyler şu şekilde düzenlenmiştir;

$$
0-4.4 \text { puan arası }=\text { Yetersiz }
$$

\section{5- 7. 4 puan arası $=$ Kısmen yeterli}

7. $5-10$ puan arası $=$ Yeterli

\section{Ölçme Araçlarının Geçerlik-Güvenirlik Çalışması}

'Okuduğunu Anlama Becerisi Testi' her biri üç seçenekten oluşan 25 maddeden meydana gelmektedir. Bayat (2012) tarafından geliştirilen Okuduğunu Anlama Becerisi testinin güvenirliği KR-20 formülü ile hesaplanarak KR-20 0.900 olarak hesaplanmış ve araştırmacı bunun yanı sıra testin madde güçlük ve madde ayırt edicilik analizlerini yaparak madde güçlük değerlerinin .47 ile .78 arasında değişmekte olduğunu hesaplamış madde ayırt edicilik değerlerinin ise .40 ile .85 arasında değişmekte olduğunu hesaplayarak maddelerin teste alınabileceğini belirlemiştir. Bu çalışmada da araştırmacı tarafından Okuduğunu Anlama Becerisi testinin güvenirliği KR-20 formülü ile hesaplanarak KR-20= 0.890 olarak hesaplanmıştır.

Bunun yanı sıra görüşme veri analizinin güvenirliğini sağlamak için araştırmacı dışında; veriler bir başka eğitim uzmanı tarafından da kodlanmıştır. Her iki araştırmacının yaptığı kodlamalar üzerinde Güvenirlik = Görüş Birliği / Görüş Birliği + Görüş Ayrılığı X 100 formülü (Miles ve Huberman, 1994; Akt. Merriam, 2009) uygulanmıştır. Yapılan iki kodlamanın uyuşum yüzdesi \%74 olarak hesaplanmıştır. 
Uyuşum yüzdesinin $\% 70$ veya üzerinde olması veri analizinin güvenirliği açısından yeterli görülmektedir.

\section{Verilerin Analizi}

Araştırmada nicel veriler, 'Okuduğunu Anlama Becerisi Testi' nin 2015-2016 eğitim- öğretim yılının 2. döneminde ilkokul 1. sınıf öğrencilerine uygulanmasıyla elde edilmiştir. Elde edilen verilerin istatistiksel çözümlemeleri için SPSS 21 veri analizi programı kullanılmıştır. Verilerin analizinin ilk aşamasında öğrencilerin OAB puanlarının aritmetik ortalamaları ve standart sapmaları hesaplanmıştır.

Nicel verilerin analizinin ikinci aşamasında bağımlı değişkenden elde edilen puanların normal dağılım özelliği gösterip göstermediği Shapiro Wilk (SW) testi ile analiz edilmiş ve puanların normalliğe uygun olmadığı ortaya çıkmıştır $(S W=0.00)$. Veriler; normallik varsayımının sağlanmadığı durumlarda kullanılan non- parametrik bir test olan, iki kategorili süreksiz bağımsız değişkenlere ait sıra ortalamaları arasındaki farklılıkları saptamaya ve ikili grupların karşılaştırmasına imkân veren Mann Whitney $U$ testi ile analiz edilmiştir.

Araştırmada öğretmen görüşme formundan elde edilen nitel verilerin çözümlenmesinde ise bir durum analizi yöntemi olan kategorisel analiz yöntemi kullanılmıştır. Kategorisel analiz yönteminde; veriler arasındaki ilişkileri ortaya çıkarmak amacıyla yazılı veya sözlü ifadelerden elde edilen veriler kodlanır ve sistematik bir şekilde sınıflandırılır (Marvasti, 2004). Bu bağlamda yazılı olarak elde edilen veriler kodlanarak, anlam benzerliklerine göre alt temalar altında birleştirilmiş, oluşturulan alt temalar ana temaların altında toplanmıştır. Nitel verilerin analizinin son aşamasında verilere göre oluşturulan temalar arasındaki anlamsal ilişkiler tespit edilerek açıklanmaya çalışılmıştır.

\section{Bulgular}

Araştırmadan elde edilen bulgular araştırma sorularının sırasına göre sunulmuştur.

\section{Okuduğunu Anlama Beceri Düzeylerine Iliş̧kin Bulgular}

Öğrencilerin okuduğunu anlama beceri düzeylerini belirlemek amacıyla uygulanan beceri testinden elde edilen verilerin birleştirilmiş sınıf ve müstakil sınıf türüne göre aritmetik ortalamaları ve standart sapmaları Tablo 2' de sunulmuştur.

Tablo 2. Öğrencilerin okuduğunu anlama beceri düzeylerine ilişkin veriler

\begin{tabular}{llll}
\hline Sınıf Türü & $N$ & $\bar{X}$ & $S S$ \\
\hline 1- Birleştirilmiş sınıf & 185 & 6.61 & 2.40 \\
2- Müstakil sınıf & 185 & 6.88 & 2.22 \\
\hline
\end{tabular}

Tabloda görüldüğü üzere birleştirilmiş sınıflarda öğrenim gören 1. sınıf öğrencilerin okuduğunu anlama beceri testinden aldığı puanların ortalaması $\bar{X}=6.61$ iken, müstakil sınıflarda okuyan 1. sınıf 
Birleştirilmiş Sınıflarda ve Müstakil Sınıflarda Öğrenim Gören 1. Sınıf Öğrencilerinin Okuduğunu Anlama Becerisinin Değerlendirilmesi

öğrencilerin puan ortalaması $\bar{X}=6.88$ olduğu belirlenmiştir. Bu durum birleştirilmiş sınıflarda öğrenim gören öğrencilerle müstakil sınıflarda öğrenim gören öğrencilerin okuduğunu anlama beceri düzeylerinin birbirine yakın değerlerde olduğunu göstermektedir. Ayrıca her iki gruptaki öğrencilerin testten aldıkları puan ortalamaları değerlendirildiğinde okuduğunu anlama becerisinin kısmen yeterli olduğu görülmektedir.

\section{Öğrencilerin Testten Aldığı Puanların Farklılaşma Düzeyine Ilişskin Bulgular}

Öğrencilerin okuduğunu anlama becerisi testinden aldığı puanların sınıf türlerine göre anlamlı bir farklılık gösterip göstermediğini belirlemek amacıyla yapılan Mann-Whitney U Testi sonuçlarına ait veriler Tablo 3' de sunulmuştur.

Tablo 3. öğrencilerin okuduğunu anlama beceri düzeylerinin Mann-Whitney U testi sonuçları

\begin{tabular}{llllll}
\hline Sınıf Türü & $N$ & $\begin{array}{l}\text { Sıra } \\
\text { Ortalaması }\end{array}$ & $\begin{array}{l}\text { Sıra } \\
\text { Toplamı }\end{array}$ & $U$ & $P$ \\
\hline Birleştirilmiş sınıf & 185 & 179.63 & 33232.00 & 16027.00 & .290 \\
Müstakil sınıf & 185 & 191.37 & 35403.00 & & \\
\hline
\end{tabular}

Birleştirilmiş sınıflarda öğrenim gören ve müstakil sınıflarda öğrenim gören 1 . sınıf öğrencilerinin okuduğunu anlama beceri testinden aldıkları puanlar arasında öğrenim gördüğü sınıf türüne göre anlamlı fark olup olmadığını belirlemek amacıyla Mann- Whitney U Testi yapılmıştır. Yapılan analiz sonucunda öğrencilerin okuduğunu anlama beceri düzeyleri arasında öğrenim gördükleri sınıf türüne göre anlamlı bir farklılık olmadığı saptanmıştır (U=16027. 0, p>. 05). Bu durumda ilkokul 1. sınıf öğrencilerinin okuduğunu anlama beceri düzeylerinin birleştirilmiş sınıfta ya da müstakil sınıfta öğrenim görmesine bağlı olarak önemli bir farklılık göstermediği söylenebilir.

Öğretmen Görüşlerine ilişkin Bulgular

Öğretmen görüşlerine ilişkin bulgular alt problemlerin sırasına göre sunulmuştur.

a) Birleştirilmiş sınıflarda öğrenim gören 1. sını öğrencilerine okuduğunu anlama beceri kazandırılırken karşılaşılan güçlüklere ilişkin öğretmen görüşleri

Öğretmen görüşleri ana temalar ve alt temalar eşliğinde sırasıyla sunulmaktadır.

Öğretmenlerin birleştirilmiş sınıflarda 1 . sınıf öğrencilere okuduğunu anlama becerisi kazandırırken hangi sorunlarla karşılaştıkları ve ne gibi güçlükler yaşadıklarıyla ilgili görüşlerine ilişkin veriler Tablo 4' te sunulmuştur. 
Tablo 4. Öğretmenlerin birleştirilmiş sınıflarda öğrencilere okuduğunu anlama becerisi kazandırmada yaşadığı güçlüklere ilişkin görüşleri

\begin{tabular}{llc}
\hline Ana tema & Alt Temalar & $f$ \\
\hline & Öğrencilerin dikkatinin dağılması & 9 \\
& Zamanın yeterli olmaması & 8 \\
Birleştirilmiş & Birebir eğitimin yapılamaması & 7 \\
sınıflarda & Öğrencilerin kavramları anlayamaması & 4 \\
karşılaşılan & Öğrencilerin hazırbulunuşluğunun yeterli düzeyde & 2 \\
güçlükler & olmaması & 2 \\
& Öğrencilerin okuma becerilerini geç kazanması & 2 \\
\hline
\end{tabular}

Tablo $4^{\prime}$ te görüldüğü üzere öğretmenlerin çoğu $(n=9)$ birleştirilmiş sınıflarda öğrencilere okuma becerisi kazandırmadaki sorunun öğrencilerin dikkatinin dağılması olduğunu ve bu durumun da genelde farklı gruptaki öğrencilerin bir arada olmasından kaynaklandığını belirtmiştir. Bu görüşteki öğretmenlerin bazılarının ifadesi şöyledir;

"Birleştirilmiş sınıflar öncelikle en büyük sıkıntıyı birinci sınıflarda yaşamakta. Çünkü birinci sınıfların zaten okula uyum konusunda pek çok sorunu oluyor bir de bunun üzerine öğrencilerin okuma yazma öğretirken diğer öğrencilerin onları sözlü ve fiili rahatsı etmesi öğrencilerin dikkatini dağıtıyor" (Ö4).

"Birleştirilmiş sınıfta öğrenim gören 1. sınıf öğrencileri 1, 2, 3 sınıf bir arada olduğu için dikkati dağılma ve diğer 2, 3. sınıfların neler yaptığını merak etme gibi sorunlarla karşı karşıya geliyor. Dolayısıla dikkatleri toparlamak bir hayli zor oluyor" (Ö18).

Ayrıca sekiz öğretmen birleştirilmiş sınıflarda öğrencilere mevcut becerileri kazandırmada zamanın yetersiz olduğunu belirtmiştir. Bu görüşle ilgili bazı ifadeler şöyledir;

"Okulda daha çok zaman ayrılamadığı için ve daha çok okuma yapılamadığı için öğrencilerin okuma hızları da beklenen düzeye gelememekte ya da geç gelmektedir" (Ö2)

"Birleştirilmiş sınıfta karşılaşılan en büyük sorunlardan birisidir okuduğunu anlamamak. Bütün sınıflarla ilgilenmek gerektiği için kazanımlara yeteri kadar zaman ayırmakta güçlük yaşanıyor" (Ö3).

Öğretmenlerin yedisi de birleştirilmiş sınıfta birebir eğitimin yapılamadığını ifade etmiştir. Bu ifadelerden bazıları da şöyledir;

"Sınıf başına düşen zaman yetersizliği, birebir eğitimin çok güç olması ve ödevlendirmede zamanı verimli geçirememeleri" (Ö5).

"Kendi başlarına okuma çalışması yapmak için görevlendirildiklerinde ilgileri çabuk dağı̆lıyor ders onlarla ilgili olmasa bile öğretmeni ve sınıfı izliyorlar. Bu durum daha çok başlarda karşılaşılabilen bir problem, daha sonra kendi kendilerine çalışmaya alışıyorlar" (Ö8). 
Birleştirilmiş Sınıflarda ve Müstakil Sınıflarda Öğrenim Gören 1. Sınıf Öğrencilerinin Okuduğunu Anlama Becerisinin Değerlendirilmesi

Sonuç olarak öğretmenlerin birleştirilmiş sınıflarda 1. sınıf öğrencilerine okuduğunu anlama becerisini kazandırmada karşılaştıkları güçlüklere ilişkin görüşleri; öğrencilerin dikkatinin dağınık olması, zamanın yetersiz olması ve öğrencilerle birebir eğitimin yapılamaması yönünde ağırlıklı olduğu görülmektedir. Bunun yanı sıra dört öğretmen okulların bulunduğu sosyoekonomik çevredeki ailelerin sosyokültürel durumlarından dolayı öğrencilerin kavramları anlayamadığını, iki öğretmen öğrencilerin hazırbulunuşluk düzeylerinin yetersiz olduğunu, öğrencilerin okuma becerilerinin geç kazandığını ifade etmiştir. Ayrıca iki öğretmende öğrencilere okuduğunu anlama becerisi kazandırırken fazla bir sorun yaşamadığını belirtmiştir.

b) Birleştirilmiş sınıf türünün 1. sınıf öğrencilerine okuduğunu anlama becerisi kazandırılmasında müstakil sınıf türüne göre üstün yanlarına ilişkin öğretmen görüşleri

Öğretmenlere birleştirilmiş sınıfın okuma becerisi kazandırmada müstakil sınıfa göre üstün yönlerine ilişkin görüşlerine ait veriler Tablo 5' de sunulmuştur.

Tablo 5. Birleştirilmiş sınıf türünün 1. Sınıf öğrencilerine okuduğunu anlama becerisi kazandırılmasında müstakil sınıf türüne göre üstün yanlarına ilişkin öğretmen görüşleri

\begin{tabular}{lll}
\hline Ana tema & Alt Temalar & $f$ \\
\hline & Birleştirilmiş sınıfların üstün bir yanı yoktur. & 6 \\
Birleştirilmiş & Üst sınıf öğrencilerin yardımcı olması & 6 \\
sınıfların üstün & Gizil öğrenmelerin gerçekleşmesi & 4 \\
yanları & Akran eğitiminden yararlanma & 3 \\
& Sınıf mevcudunun daha az olması & 1 \\
& Bireysel ders çalışma sorumluluğunun kazanılması & 1 \\
\hline
\end{tabular}

Tabloda görüldüğü üzere öğretmenlerin altısı birleştirilmiş sınıflarda okuma becerisinin kazandırılmasına ilişkin müstakil sınıflara göre üstün bir yanının olmadığı görüşündedir $(n=6)$. Öğretmenlerden bazıları bu görüşleri şöyle ifade etmiştir;

"Birleştirilmiş sınıfta okuduğunu anlama konusunda müstakil sınıfa göre üstün yanları olduğunu düşünmemekteyim. Öğrencilerle ilgilenme açısından çok fark olduğunu düşünmekteyim. Fakat akran eğitimi konusunda fayda sağlayabileceğini söyleyebilirim. Birleştirilmiş sınıfta 1. sınıf öğrencisi üst sınıftaki öğrencilerden faydalanarak kendini geliştirebilir" (Ö17).

"Birleştirilmiş sınıfların 1. sınıf öğrencileri, müstakil sınıflara göre üstün yanı vardır ya da yoktur demek yanlış olur. Bunu söylemek için Birleştirilmiş sınıfın mevcudu, fiziksel durumu, aile, yaşantı vb. gibi dinamiklerin rolü büyüktür. Genel olarak yorumlayacak olursak üstün yanı yoktur" (Ö20).

Ayrıca öğretmenlerin altısı birleştirilmiş sınıfların üstün yanı olarak üst sınıf öğrencilerinin birinci sınıf öğrencilerine yardımcı olması olduğunu belirtmiştir. Bununla ilgili öğretmen görüşlerinin bazıları şöyledir: 
"Birleştirilmişs sınıfta okuduğunu anlama becerisinin kazandırılırken müstakil sınıfa göre avantajı üst sınıf öğrencilerin 1. Sınıf öğrencilerine yardımcı olmasıdır. Bunun da fark yaratacak kadar etki yaptığını düşünmüyorum" (Ö3).

"Birleştirilmiş sınıflarda, üst sınıflarda okuyan öğrenciler 1. sınıflara yardımcı olduklarından anlama konusunda daha iyi olabilir" (Ö7).

Sonuç olarak öğretmenlerin çoğunluğu birleştirilmiş sınıflarda öğrencilere okuduğunu anlama becerisinin kazandırımasında üstün yanının olduğu görüşündedir $(n=13)$. Araştırmaya katılan öğretmenlerin altısı üst sınıf öğrencilerin birinci sınıflara okuduğunu anlama konusunda yardımcı olması açısından birleştirilmiş sınıfların daha elverişli ve avantajlı olduğunu düşünmektedir. Bu görüşü birleştirilmiş sınıflarda gizil öğrenmelerin gerçekleşmesi $(n=4)$, akran eğitiminden yararlanma $(n=3)$, sınıf mevcudunun daha az olması $(n=1)$ ve bireysel ders çalışma sorumluluğun kazanılması $(n=1)$ görüşleri izlemektedir.

c) Birinci sınıf öğrencilerinin okuduğunu anlama beceri durumları arasındaki farka ilişkin öğretmen görüşleri

Öğretmenlere birleştirilmiş sınıflar ile müstakil sınıflarda öğrenim gören birinci sınıf öğrencilerinin okuduğunu anlama becerileri arasında fark olup olmadığı sorulmuştur. Öğretmenlerin bu konuya ilişkin görüşlerine ait veriler Tablo 6’ da sunulmuştur.

Tablo 6. Birinci Sını Öğrencilerinin Okuduğunu Anlama Beceri Arasındaki Farka ilişkin Görüşleri

\begin{tabular}{llc}
\hline Ana tema & Alt Temalar & $f$ \\
\hline \multirow{2}{*}{$\begin{array}{l}\text { Okuduğunu anlama } \\
\text { başarıları arasındaki fark }\end{array}$} & Müstakil sınıf daha başarılı & 15 \\
& Başarılar arasında fark yok & 3 \\
& Kararsızım & 2 \\
\hline
\end{tabular}

Tabloda görüldüğü üzere öğretmenlerin büyük bir çoğunluğu $(n=15)$ müstakil sınıflardaki birinci sınıf öğrencilerin okuduğunu anlama becerisi konusunda daha başarılı olduğunu düşünmektedir. Müstakil sınıfta öğrenim gören öğrencilerin okuduğunu anlama beceri başarısının daha iyi olduğunu belirten sekiz öğretmen, birleştirilmiş sınıflarda birinci sınıf öğrencilerine yeterli zaman ayrılamadığı, altı öğretmen sınıflarda farklı grupların bir arada ders işlemesi gerektiği, üç öğretmen de öğrencilere yeterli ilgi gösterilemediği için bu öğrencilerin müstakil sınıf öğrencilerinden daha düşük düzeyde başarı gösterdikleri görüşündedir. Öğretmenlerin bazıları bu konuyla ilgili şu görüşleri belirtmişlerdir;

"Müstakil sınıf her zaman birleştirilmiş sınıfa göre daha avantajlıdır. Daha fazla zaman harcanan bir eğitim aynı metotlarla uygulandığında daha verimli olur. Bu yüzden müstakil sınıfların okuduğunu anlama düzeylerinin birleştirilmiş sınıflara göre daha üst düzeyde olacağını düşünüyorum" (Ö1). 
Birleştirilmiş Sınıflarda ve Müstakil Sınıflarda Öğrenim Gören 1. Sınıf Öğrencilerinin Okuduğunu Anlama Becerisinin Değerlendirilmesi

"Okuduğunu anlama durumlarında fark oluyor. Birleştirilmiş sınıflarda birebir ilgilenme süresi daha az olduğu için algılama süresi uzuyor. Müstakil sınıflarda birebir ilgilenme ve aynı konu işlendiğinden dolayı kavrama olayı daha çabuk gerçekleşiyor" (Ö16).

"Müstakil sınıflar daha başarılıdır. Aynı konular, aynı etkinliklerle beraber olduğu için başarı artmaktadır. Birleştirilmiş sınıfta okuyan öğrenciler bu konuda oldukça şanssız" (Ö17).

Okuduğunu anlama başarısı açısından müstakil sınıf ve birleştirilmiş sınıf öğrencileri arasında fark olmadığına yönelik görüş bildiren bazı öğretmelerin ifadeleri de şöyledir;

"Fark görmüyorum, ikisinde de görev yapan biri olarak. Birleştirilmiş sınıfta öğretmenin biraz daha planlama yükü fazla oluyor. İyi planlanmış bir eğitim ortamında birleştirilmişsınıf daha yararlı bile olabiliyor" (Ö8).

"Fark görmüyorum. Her ikisinde de aynı zamanlarda okuma -yazmaya geçiliyor. Birleştirilmiş sınıfta biraz daha yoğun program olduğundan öğretmen daha fazla yoruluyor" (Ö6).

Sonuç olarak öğretmenlerin çoğu zaman, ilgi ve ders işlenişi açısından müstakil sınıf öğrencilerinin okuduğunu anlama başarılarının birleştirilmiş sınıftaki öğrencilerden daha iyi düzeyde olduğu yönünde görüş bildirmiştir.

d) Hangi sınıf türünde okuma becerisini kazandırmada daha çok güçlük çektiklerine ilişkin öğretmen görüşleri

Öğretmenlerin hangi sınıf türünde okuma becerisini kazandırırken daha çok güçlük çektiklerine ilişkin görüşleri sorulmuştur. Öğretmenlerin bu soruya ilişkin cevaplarına ait veriler Tablo $7^{\prime}$ de sunulmuştur.

Tablo 7. Hangi sınıf türünde okuma becerisini kazandırmada daha çok güçlük çektiklerine ilişkin görüşler

\begin{tabular}{|c|c|c|}
\hline Ana tema & Alt Temalar & $f$ \\
\hline Hangi & Birleştirilmiş sınıfta güçlük çektim & 12 \\
\hline türünde güçlük & Her ikisinde de güçlük çekmedim & 7 \\
\hline çektikleri & Müstakil sınıfta güçlük çektim & 1 \\
\hline
\end{tabular}

Tabloda görüldüğü üzere öğretmenlerin büyük bir çoğunluğu $(n=12)$ birleştirilmiş sınıflarda okuma becerisini kazandırmada daha çok güçlük çekildiğini düşünmektedir. Öğretmenlerin bazıları bu konuyla ilgili şu görüşleri belirtmişlerdir;

"Birleştirilmiş sınıfta okuma becerilerini geliştirme daha zordu. Öğrencilere evde yardıma olunmuyordu, çocuklara ayırdığımız süre kısıtııdı" (Ö5).

"Birleştirilmiş sınıflarda bu zorluğu daha çok çektiğim söylenebilir. Bunu da zamana bağlayabiliriz" (Ö7). 
Okuma becerisini kazandırırken her iki sınıf türünde de güçlük çekmediklerine yönelik görüş bildiren bazı öğretmelerin ifadeleri de şöyledir;

"Veli işbirliği çok iyi olduğundan dolayı ikisinde de her hangi bir güçlük çekmedim" (Ö18)

"Her iki sınıfta da okuma becerileri kazandırırken güçlükle karşılaşmadım” (Ö14).

Okuma becerisi kazandırırken müstakil sınıf türünde daha çok güçlük çektiğine yönelik görüş bildiren öğretmenin ifadeleri de şöyledir;

"Müstakil sınıfta sınıf mevcudunun fazla olmasından ve evde çocukların ödev kontrolünün olmamasından dolayı daha çok güçlük çektiğim söylenebilir" (Ö10).

Sonuç olarak öğretmenler 1. sınıf öğrencilerine okuma becerisini kazandırırken müstakil sınıfta daha az güçlük çekmelerine rağmen birleştirilmiş sınıfta daha çok güçlük çektikleri yönünde görüş bildirmiştir.

\section{Tartışma, Sonuç ve Öneriler}

Araştırmadan elde edilen bulgulara göre her iki sınıf türünde de öğrencilerin okuduğunu anlama beceri düzeyi kısmen yeterli düzeydedir. Öğrencilerin okuduğunu anlama beceri düzeylerini artırmak için okuma saatlerini artırma, kitap okuma alışkanlığını geliştirici etkinlikler düzenleme, öğrenci aktivitesine dayanan okuduğunu anlama etkinlikleri düzenleme gibi önlemler alınabilir.

Birleştirilmiş sınıf ve müstakil sınıflarda öğrenim gören öğrencilerin okuduğunu anlama becerilerinin incelendiği bu çalışmada birinci sınıf öğrencilerinin okudukları sınıf türüne göre okuduğunu anlama becerileri arasında anlamlı bir farklılık olmadığı tespit edilmiştir. Benzer bir şekilde Berry (2001) birleştirilmiş ve bağımsız sınıf öğrencilerinin okumadaki ilerlemelerini karşılaştırdığı çalışmasında Karayipler' deki küçük bir adada, yedisi bağımsız, üçü birleştirilmiş olmak üzere toplam on okulda yürütülmüştür. Veriler, okuma başarısını belirlemeye yönelik olan gözlemsel bir çalışmadan elde edilmiş olup, 1993-1996 yılları arasında üç yıl gibi uzun bir sürede toplanmıştır. Rastgele seçimle deney ve kontrol grubuna yerleşen öğrenciler, başlangıçta bir okuma ön-testine alınarak; düşük, orta ve yüksek başarı seviyeleri oluşturulmuştur. Araştırma sonucunda özellikle birleştirilmiş sınıftaki düşük başarılı öğrencilerin bağımsız sınıftaki öğrencilerden okumada tüm yıllarda daha iyi ilerlediği sonucuna ulaşırken, orta ve yüksek başarı düzeyindeki 8-9 yaş grubu çocukların başarıları arasında bir fark bulunamamıştır. Bağımsız sınıftaki 9-10 yaş arası orta ve yüksek başarı seviyesindeki çocuklar birleştirilmiş sınıftakilere göre daha iyi okuma başarısı elde etmiştir. 8-10 yaş arası grupta orta seviyedeki çocuklar arasında bir fark yokken, yüksek başarı seviyesindeki çocuklarda birleştirilmiş sınıf lehine anlamlı sonuçlar bulunmuştur. Araştırmada özellikle çocukların düşük okuma düzeyini geliştirmede birleştirilmiş sınıfların etkili olduğu sonucuna ulaşılıştır. Benzer bir çalışmayı da 
Birleştirilmiş Sınıflarda ve Müstakil Sınıflarda Öğrenim Gören 1. Sınıf Öğrencilerinin Okuduğunu Anlama Becerisinin Değerlendirilmesi

Wilkinson ve Hamilton (2003) yürütmüş, birleştirilmiş sınıflar ve müstakil sınıflarda öğrenim gören öğrencilerin okuma başarılarının farklı olmadığını tespit etmiştir.

Okuma başarısının yanı sıra bu araştırma sonuçlarını destekler nitelikte müstakil ve birleştirilmiş sınıflarda okuyan öğrencilerin genel akademik başarılarının karşılaştırıldığı çalışmalarda (Kadivar, Nejad ve Emamzade, 2005, Quail ve Smyth, 2014; Veenman, 1995; ) da öğrenim görülen sınıf türünün akademik başarıda etkili olmadığı tespit edilmiştir. Ancak literatürde (Bayat ve Çoşkun, 2016; Karaman, 2006; Mason ve Burns 1996; Russell, Rowe ve Hill, 1998) birleştirilmiş sınıflarda öğrenim öğrencilerin müstakil sınıflarda öğrenim gören öğrencilere göre akademik başarılarının daha düşük olduğu sonucuna ulaşılan çalışmalar da bulunmaktadır. Bu durumda öğrenim görülen sınıf türünün akademik başarı üzerindeki etkisine ilişkin bir yargıya varmanın güç olduğu söylenebilir. Wilkinson ve Hamilton'a (2003) göre en azından okuma başarısında öğrenim görülen sınıf türü etkili değildir ve akademik başarıda etkili olan sınıf içi öğretimin niteliğidir.

Araştırma sonuçları müstakil sınıf ve birleştirilmiş sınıf öğrencileri arasında okuduğunu anlama becerisi arasında anlamlı bir farklıı̆̆ın olmadığını göstermiştir. Ancak öğretmenler ile yapılan görüşmelerden elde edilen bulgulara göre öğretmenlerin çoğunluğu okuduğunu anlama becerisi açısından müstakil sınıfların birleştirilmiş sınıflara göre daha başarılı olduğu görüşündedir. Öğretmenler birleştirilmiş sınıflarda okuduğunu anlama becerisi kazandırmada birleştirilmiş sınıfların doğası onlara yeterli zaman ayıramama, öğrencileri ile birebir ilgilenme fırsatı bulamama, öğrencilerin hazırbulunuşluluk düzeyinin düşük olması ve diğer sınıflarla öğretmenli ders yaparken dikkatlerinin dağılması gibi nedenlerle güçlük çektikleri görüşündedirler. Öğretmenlerin birleştirilmiş sınıflarda ders sürecinde daha fazla problemle karşılaşması birleştirilmiş sınıflarda öğrenim gören öğrencilerin müstakil sınıflara göre daha başarısız olduğu görüşünün ağırlık kazanmasına neden olduğu söylenebilir. Mason ve Burns (1996) da sınıf türünün akademik başarıda etkisinin çok az olmasına rağmen birleştirilmiş sınıflarda öğretmenlerin motivasyonlarının düşük olduğunu vurgulamaktadır.

Öğretmenlerin birleştirilmiş sınıflarla ilgili genel görüşleri incelendiğinde birletilmiş sınıfların; akran öğretiminden yararlanma, üst sınıfların alt sınıflara yardımcı olması, bireysel çalışma sorumluluğu kazanma gibi üstün yanlarının olmasına rağmen, genel olarak birleştirilmiş sınıf uygulamalarında daha çok güçlükle karşılaştıkları ve başarının müstakil sınıflara oranla düşük olduğu görüşündedirler. Literatürde birleştirilmiş sınıflarla ilgili öğretmen görüşlerinin incelendiği çalışmalar bu çalışma sonuçlarını destekler niteliktedir. Örneğin, Çınar (2003) araştırmasında birleştirilmiş sınıflı okullarda öğretmenlerin her sınıfa gerektiği kadar zaman ayıramadıkları, okullarda materyal eksikliğinin bulunduğu, velilerin yeteri kadar ilgili olmadıkları, birleştirilmiş sınıflarda öğrenim veren öğretmenlerin özlük hakları, sosyal ve ekonomik olarak özendirici olmadığı sonucuna ulaşmıştır. 
Bir başka araştırmada Dursun (2006), birleştirilmiş sınıflarda eğitimin; etkileşim, yardımlaşma ve kaynaşma, akran öğretimi vb. açılardan yararlı olduğunu belirtmiştir. Ancak zamanın yetersizliği, velilerin eğitime olumsuz bakış açısı, materyal eksikliği, köylerde sağlık, ulaşım ve iletişim gibi problemlerin yaşanması gibi pek çok problemin devam ettiği de vurgulamaktadır. Bayar (2009), çalışmasında öğretmenlerin bir sınıfla ilgilenirken diğer öğrencilerin dikkatlerinin dağılması gibi sorunlar yaşamaları, müstakil sınıflara göre sınıf yönetiminde daha çok sorunla karşılaşılması, öğretmenlerin zaman sıkıntısı yaşamaları, öğretmenlerin materyal eksiği yaşamaları gibi durumların eğitim öğretimi sınırlandırdığını sonucuna ulaşmıştır.

Öğretmenlerin birleştirilmiş sınıflarda daha çok güçlükle karşılaşmalarına ve müstakil sınıflara göre birleştirilmiş sınıfların dezavantajlarının daha fazla olmasına rağmen akademik başarıda fark tespit edilememesi çarpıcıdır. Bunun nedeni genel olarak birleştirilmiş sınıflarda görev yapan öğretmenlerin mesleğinin ilk yıllarında olmalarından dolayı performanslarının ve iş motivasyonlarının daha yüksek olması olabilir. Bu düşünceden hareketle birleştirilmiş sınıflarda görev yapan öğretmenlerin iş motivasyonlarının yüksek tutulması ve performanslarının artırılması için eğitim odaklı toplantılar, sosyal etkinlikler, eğitim odaklı geziler düzenlenebilir.

Öğretmenler birleştirilmiş sınıflarda daha çok güçlükle karşılaştıklarını belirtmişlerdir. MEB desteği ile birleştirilmiş sınıfların dezavantajlarını en aza indirecek ücretli ek ders saatleri ve bireysel çalışma saatleri düzenlenmesine fırsat verecek önlemler alınabilir.

Bu çalışma Ağrı ile ve birinci sınıflarda okuduğunu anlama becerisinin incelenmesi ile sınırlıdır. Birleştirilmiş sınıf ve müskakil sınıfların akademik başarısının karşılaştırılacağı daha geniş çaplı araştırmalar yapılabilir. Ayrıca yapılacak araştırmalardan elde edilen bulgulara göre akademik başarı ya da başarısızlığın nedenleri araştırılabilir.

\section{Kaynaklar}

Akbaşlı, S. \& Pilten, Ö. (1999). Birleştirilmiş Sınıflarda Öğretim. Mikro Yayıncılık Konya.

Akyol, H. (2010). Yeni programa uygun Türkçe öğretim yöntemleri (3. Baskı). Ankara: Pegem Akademi.

Bayar, S. A. (2009). Sınıf öğretmenliği eğitimi anabilim dalı 4. sınıf öğrencilerinin birleştirilmiş sınıflar hakkındaki görüşleri: Gazi Üniversitesi Örneği. Ankara: Gazi Üniversitesi Eğitim Bilimleri Enstitüsü, Yayımlanmamış Yüksek Lisans Tezi.

Bayat, S. (2012). Stake'in Uygunluk/Olasılık Modeline Göre Ilkokuma Yazma Programının Değerlendirilmesi. Bolu: AiBÜ. Eğitim Bilimleri Enstitüsü, Yayınlanmamış Doktora Tezi.

Bayat, S. \& Çoşkun, M. (2016). Illkokul ikinci sınıf öğrencilerinin yazma başarısının okudukları sınıf türüne göre incelenmesi. Sakarya Üniversitesi Eğitim Fakültesi Dergisi, 31, 60-73.

Creswell, J. W. \& Plano Clark V.L.(2014). Karma yöntem araştırmaları. (Trans. Eds. Dede, Y. \& Demir S. B.) Ankara: Anı Yayıncilık.

Çelenk S.(2001). Ilkokuma - yazma programı ve öğretimi. Ankara: Artım Yayınları. 
Birleştirilmiş Sınıflarda ve Müstakil Sınıflarda Öğrenim Gören 1. Sınıf Öğrencilerinin Okuduğunu Anlama Becerisinin Değerlendirilmesi

Çınar, i. (2004). Birleştirilmiş sınıflı ilköğretim okullarında ilkokuma yazma öğretimine ilişkin bir araştırma. Inönü Üniversitesi Eğitim Fakültesi Dergisi, 5(7), 31-45.

Demirel, Ö. (1998). Türkçe program ve öğretimi. Ankara: USEM.

Dursun, F. (2006). Birleştirilmiş sınıflarda eğitim sorunları ve çözüm önerileri. Sosyal Bilimler Araştırmaları Dergisi. 2, 33-57.

Erdem, A.R. (2015). Birleştirilmiş sınıflarda öğretim (7. Basım). Ankara: Anı Yayıncılık.

Fidan, N. \& Baykul, Y.(1997). Birleştirilmiş sınıflarda öğretim öğretmen rehberi. Ankara: MEB ve UNICEF.

Kadivar, P., Nejad, S. N., \& Emamzade, Z. M. (2005). Effectiveness of multi-grade classes: Cooperative learning as a key element of success. World Academy of Science, Engineering and Technology,(8).169-172.

Karaman, F.( 2006). Birleştirilmiş sınıflarda matematik dersindeki başarı düzeyi ile normal sınıflardaki başarı düzeyinin karşılaştırılması. Van: Yüzüncü Yıl Üniversitesi Sosyal Bilimler Enstitüsü, Yayımlanmamış Yüksek Lisans Tezi,

Little, A. (1994). Multigrade teaching: A review of practice and research (Vol. Education Research Paper 12, p. 63). London: Overseas Development Administration.

Marvasti, A. B. (2004). Qualitative research in sociology. London: SAGE Publication.

Mason, D. A., \& Burns, R. B. (1996). "Simply no worse and simply no better" may simply be wrong: A critique of Veenman's conclusion about multigrade classes. Review of Educational research, 66(3), 307-322.

Merriam, S. B. (2009). Qualitative research: A guide to design and implementation. San Francisco: Jossey-Bass.

Miles, M. B., \& Huberman, A. M (1994). Data management and analysis methods. In N. K. Denzin \& Y. S. Lincoln (Eds.), Handbook of qualitative research (pp. 428-444). Thousand Oaks, CA, US: Sage Publications, Inc.

Miller, B. A. (1991). A Review of the Qualitative Research on Multigrade Instruction. Erişim: https://files.eric.ed.gov/fulltext/ED342563.pdf. ERIC ED: 342563

Quail, A., \& Smyth, E. (2014). Multigrade teaching and age composition of the class: The influence on academic and social outcomes among students. Teaching and Teacher Education, 43, 80-90.

Palavan, Ö. (2012). Birleştirilmiş ve bağımsız sınıflı ilköğretim 4. sınıf öğrencilerinin sosyal bilgiler kazanımlarına erişim düzeyleri. Ondokuz Mayıs Üniversitesi Eğitim Fakültesi Dergisi, 31 (2) 281-294

Russell, V. J., Rowe, K. J., \& Hill, P. W. (1998). Effects of Multigrade Classes on Student Progress in Literacy and Numeracy: Quantitative Evidence and Perceptions of Teachers and School Leaders. Erişim: https://files.eric.ed.gov/fulltext/ED444122.pdf, ERIC ED: 444122

Veenman, S. (1995). Cognitive and noncognitive effects of multigrade and multi-age classes: A best-evidence synthesis. Review of educational research, 65(4), 319-381.

Wilkinson, I. A., \& Hamilton, R. J. (2003). Learning to read in composite (multigrade) classes in New Zealand: teachers make the difference. Teaching and Teacher Education, 19(2), 221-235.

\section{Extended Abstract}

Introduction

Combining more than one grade to create a group to be taught by a single teacher is referred to as multigrade teaching. In our country, multi-grade classroom teaching practice is done due to reasons such as low number of students, low number of teachers and inadequate number of classrooms. Besides these reasons, the different social, economic and geographical reasons of our country necessitate multi-grade class teaching. Teaching in multi-grade classes differs from teaching in single-grade classes. In the multi-grade classroom, the system is set up to allow the group to work on their own, with lessons being taught by a group of teachers. The aim of elementary school teaching is not only to develop literacy (Demirel, 1998), but also to develop a skill in reading comprehension that is accurate, fluent, fast, and meaningful. The type of class in which individuals are taught to read to comprehend has a very important place in their education. For this reason, it is considered that 
comparing the reading comprehension skill levels of the first grade students in multi-grade and single-grade classrooms will contribute to the field.

Method

In this study, the aim was to examine whether there was a meaningful difference between the reading comprehension skill levels of elementary school students in single-grade and multi-grade classrooms and to evaluate the opinions of teachers who taught in such classes. Descriptive mixed method in which qualitative and quantitative research designs are used together was used in this study. Quantitative data from the students were collected and analyzed at the first stage; the qualitative data were collected and analyzed by the researchers at the next stage, and, finally, the results were interpreted altogether.

\section{Results and Discussion}

This study examined the comprehension skills of the students in the multi-grade and the single-grade classes and found that there was no significant difference in the ability of first grade students in understanding what they read based on the class type they attended. The research results showed that there was no significant difference between their comprehension skills. However, the findings of the interviews with teachers showed that the majority of the teachers thought that single-grade classes were more successful than the multi-grade classes in terms of their ability to understand what they read. Teachers experience difficulties in multi-grade classes because they do not have enough time to get involved with all students, the readiness level of the students is low and their attention is disrupted while teaching other classes. It can also be said that as the teachers in multi-grade classes encounter more problems, that causes students in those classes to think that they were less successful than the students in single-grade classes. It is striking that despite the difficulties faced by teachers in multi-grade classes and the disadvantages of multi-grade classes compared to single-grade classes, no significant difference in academic achievement could be determined. This may be due to the fact that teachers who work in multi-grade classes are younger, and, therefore, have higher performance and work motivations. 